\title{
静水中に瞬間的に投下された重たい 流体塊の流動特性に関する研究 FLOW CHARACTERISTICS OF DENSE CLOUD INSTANTANEOUSLY RELEASED INTO QUIESCENT FLUID
}

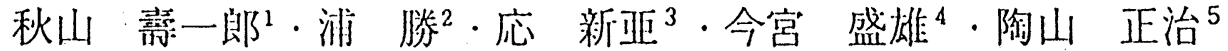 \\ Juichiro AKIYAMA, Masaru URA, Xinya YING, Morio IMAMIYA and Masaharu SUYAMA \\ ${ }^{1}$ 正会貝 Ph.D. 九州工業大学助教授 工学部建設社会工学科 (厂 804 北九州市戸畑区仙水町 $1 \cdot 1$ ) \\ ${ }^{2}$ 正会貝 工博 九州工染大学教授 工学部建設社会工学科 (同上) \\ 3学生貝 九州工盖大学大学院 工学研究科博士後斯倸程 (同上) \\ 4 学生貝 九州工染大学大学院 工学咞究科博上前期稆程 (同上)

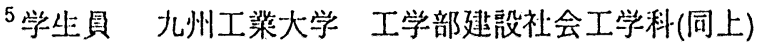

\begin{abstract}
Motion of conservative two-dimensional free thermals is investigated experimentally and theoretically. A series of laboratory experiments is conducted to obtained flow characteristics of the flow and several important empirical relations are formulated. An integral model is developed, using such empirical relationships as the shape factors, entrainment function, drag coefficient and others. A set of solutions are obtained analytically and numerically. Comparisons between calculated and experimental results are also presented. It is found that the model performs well in predicting the motion of free thermals and that the following relationships exist for fully developed free thermals : $\mathrm{H} \sim \mathrm{Z} ; \mathrm{V} \sim \mathrm{Z}^{-1 / 2} ; \mathrm{B} \sim \mathrm{Z}^{-2}$.
\end{abstract}

Key Words : density current, vertical free thermal, integral model, experiment

\section{1.はじめに}

近作、洲合における海上空港、沿岸・港游域にお けるウォーターフロントなどの建設を目的とした水 域への土砂投下工事が各地で行われている。この際、 経済性を考虑して、底關バージによる上砂直投工が 用いられるのが通常である。しかし、直投工では微 絥土粒子を含む多量の土砂が水面付近から投入され るため、土粒子の流動・搪散による大嫢模な污罚が 発生することが大きな間題となっている。

玉井ら ${ }^{1)}$ はこのような上仯投下問題を刘象とし て、静水中に橓間的に投下された粒子稀の落下挙動 特性について調べ、粒径が大きく投下量が少ない場 合には、個々の粒子の自由沫降的な落下形態となり、 粒径が小さく投下量が多い場合には、粒子群として 流動する乱流サーマル的な落下形態となることを実 験的に明かにした。その上で、Baines and Hopfinger ${ }^{2)}$ による単相乱流少ーマル理論と実駼值 との比較検討を行なうとともに、乱流少ーマル理論 を拡涱することにより、自由沈降的落下挙氆と乱流
サーマル的落下举秒を統一的に説明するための固液 混相の乱流サーマル理諭を提案している。従って、 玉井ら ${ }^{1)}$ の理論モデルはWang ${ }^{3)} 、$ Escudier and Maxworthy ${ }^{4)}$ 、Baines and Hopfinger ${ }^{2)}$ などの一速 の乱流将マルに関する㑚究の延長線上にあるもの であるが、乱流サーマル理諭を混相流に発展させた 点が評何される。

以下では、間単にこれらの研究をレビューし、そ れぞれの硍究の特微と問题点を明かにする。 Wang ${ }^{3)}$ は、質量、運動量およびエンタルピーの保 存に基づき、一棣でない大気中の3次元镃浮力サー マルの流怔解析を行なっている。特に、小規模な实 験空スケールのサーマルと大規模な大気中のサーマ ルとの間のスケーリング関係を谷易にした点が注目 される。しかし、付加質量の概念が考䈍されていな い、抵抗係数の決定方法が不明である、实騟値と理 諭値との比較検討が行なわれていない、速行係数の 算出方法が明らかではない、などの問題点を有して いる。Escudier and Maxworthy ${ }^{4}$ は、Wang ${ }^{3)}$ の研究 で久落していた付加質量を無視することから生じる。 
表-1 笑験条件

\begin{tabular}{|c|c|c|c|}
\hline & $\begin{array}{c}\text { 初期相対遙度管 } \\
\varepsilon_{0}\end{array}$ & $\begin{array}{c}\text { 初期站位幅体敌 } \\
\mathrm{A}_{0}\left(\mathrm{~cm}^{2}\right)\end{array}$ & $\begin{array}{c}\text { 初期松有効近力 } \\
W_{0}\left(\mathrm{~cm}^{3} / \mathrm{s}^{2}\right)\end{array}$ \\
\hline CASE $\cdot 1$ & \multirow{3}{*}{0.26} & 0.80 & 203.84 \\
\hline CASE-2 & & 1.15 & 2.93 .02 \\
\hline CASE-3 & & 1.50 & 380.20 \\
\hline CASE 4 & \multirow{3}{*}{0.32} & 0.65 & 203.84 \\
\hline CASE- 5 & & 0.95 & 2.97 .92 \\
\hline CASE 6 & & 1.25 & 3.92 .00 \\
\hline CASE-7 & \multirow{3}{*}{0.38} & 0.55 & 204.82 \\
\hline CASE- 8 & & 0.80 & 2.97 .92 \\
\hline CASE 9 & & 1.05 & 391.02 \\
\hline
\end{tabular}

矛盾を指摘するとともに、付加質量を考虑した運動 方程式を導入し、熱浮力サーマルの理論モデルを棈 築している。しかし、流体抵抗が考虑されていない、 連行係数の算出方法が明礁ではない、实験值と理論 值との比較検討が行なわれていない、などの問題点 を有している。Baines and Hopfinger ${ }^{2)}$ は、非ブ シネスクサーマルを刘嗮として、周困との密度差が 大きく柽いサーマルと周围との密度差が大きく重い サーマルの実験を行ない、その成長率を解析し、大 きな密度差の影響が点源近くの筙囲に限定されるこ となどを明らかにしている。しかし、流体抵抗が考 愿されていない、現実原点から仮想原点までの距蛜 を与える関係を導いているが、実験值との比較検討 が行なわれていない、サーマルの成言率について実 験值と比較検討しているが、密度および重心降下速 度については比較検討が行なわれていない、速行係 数の概念が通常のものと異なる、などの問題点を有 している。最後に、玉井ら ${ }^{1)}$ の矿究では、流体抵 抗が考虑されていない。乱流サーマルの実験結果と の比較検討が行なわれていない。速行係数の与方方 に任意性がある、密度に関する実険値との比較検討 うおなされていない、などの問題点を有している。こ のように、乱流少ーマルを対象として、数多くの理 諭的・实験的研究がなされているが、抵抗係数や速 行係数などの諸量が明確に定量化されているわけで はなく、さらに、理諭モデルの実験的検証も必ずし も十分に行なわれているわけではない。

本研究は、土砂投下にともなう微細土粒子の水質 污濁問題を対象として、その流坵特性の㑇明のため の基本となると考えられる粼水中を降下寸る保存性 2次元乱流サーマルの流㖄特性について理諭的・实 験的に検討を加えるとともに、抵抗係数や速行係数 などの特性量の定量化を行ない、流軼特性に対する それらの効果について考察を加えたものである。

\section{2. 実験}

実験装犆は、前面アクリル製の水档(幅 $1.5 \mathrm{~m}$ 、深 さ $1.5 \mathrm{~m}$ 、奥行き $0.1 \mathrm{~m})$ に流入箱を取り付けたもので

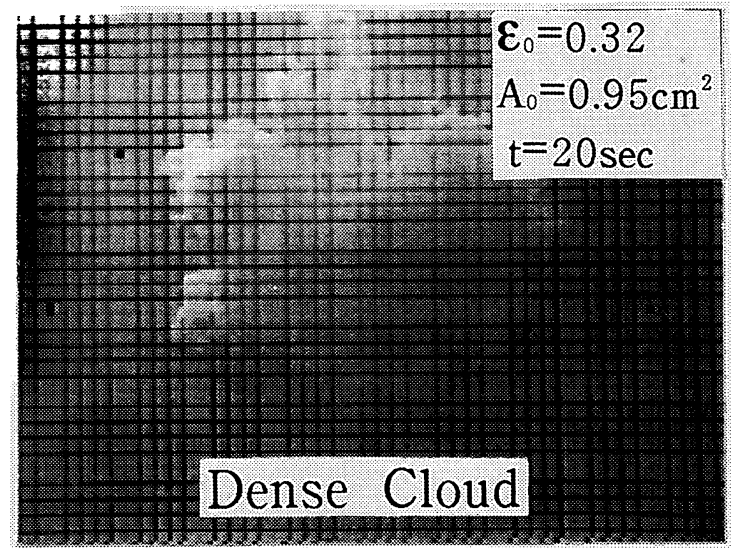

图-1 自由サーマルの流況

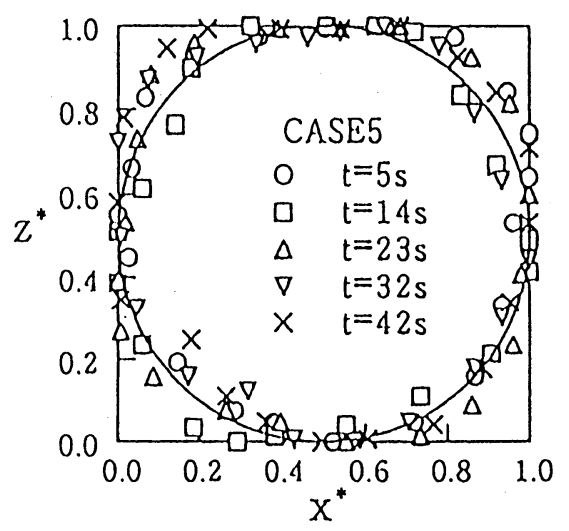

图-2 照次元形状

ある。密度 $\rho_{2}$ の背水中に単位幅体積 $\mathrm{A}_{0}$ の投下装置か ら初期密度 $\rho_{0}$ の塩水を水表面より僢間的に流入させ、 塩水サーマルを発生させた。このようにして形成さ れたサーマルの流動状況をサーマルと同じ速度で VTRカメラを移動させながら水棌側面より撮影を行 なった。高性能VTRに収録された画像を解析するこ とにより、重心降下速度 Vおよびサーマル形状を求 めた。流れの再現性は比較的良好であったので、5 回の繰り返し実臨を同一条件下で行ない、データの 信頼性を高めた。実験条件を表1に示す。実験条件 は初期総有效重力W $\left.W_{0}=\mathrm{A}_{0} \varepsilon_{0} \mathrm{~g}\right)$ が 3 通りになるように 初期相対密度差 $\varepsilon_{0}\left(=\left(\rho_{0}-\rho_{\mathrm{a}}\right) / \rho_{\mathrm{a}}\right)$ と初期単位幅体皘 $A_{0}$ を変化させた計9通りである。

\section{3. 理論的考察}

図1にCASE5の塩水サーマル $\left(\varepsilon_{0}=0.32 、 \mathrm{~A}_{0}=\right.$ $\left.0.95 \mathrm{~cm}^{2}\right)$ の流動状況の一例を示す。これより、塩水 サーマルはほほ左右対称の循環流より構成されて おり、激しく周困流体をサーマル内部に取り込み ながら発達していく様子がわかる。図2はサーマル を水平方向に最大幅Hで、鉛直方向に最大長さLで 正规化した㫮次元形状と円との比較を示したもの であるが、これより、サーマルはほほ楕円形状の 相似形を保ちながら落下することわかる。そこで 
以下では、サーマルを図3のようにモデル化して考 える。たたし、図中のV.O.は塩水少ーマルの最大高 さが䎧となる仮想原点(Virtual Origin)である。現经 のモデル化に当たって、(1)州ーマル内部は完全混 合状照である、(2)初期淞有效兵力は保存される、 (3)ブシネスク辛ーマルであると仮定する。

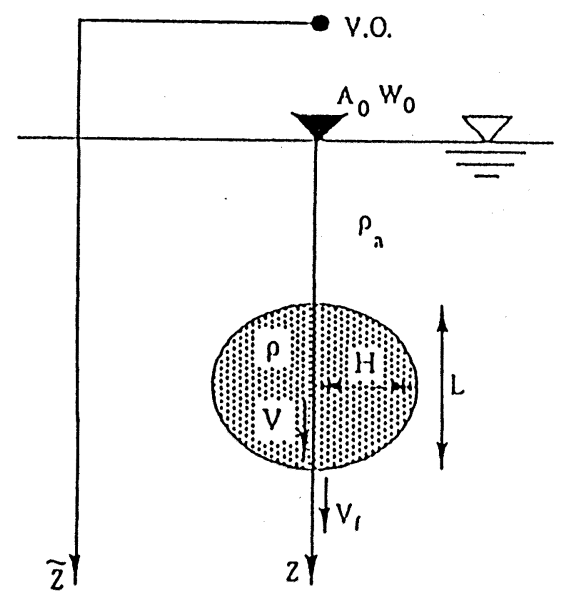

图-3，定䇅図

図3で定義される乱流少ーマルの断面稓Aおよび 周畔長Cはそれそれれ次式のように婊わされる。

$$
\begin{aligned}
& A=2 S_{1} H L \\
& C=S_{2} \sqrt{H L}
\end{aligned}
$$

ここに、L=サーマルの最大艮さ、H=リーマルルの

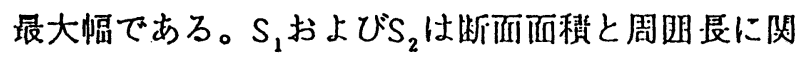
する形状俰数であり、それそれ次式で与えられる。

$$
\begin{gathered}
S_{1}=\frac{\pi}{4} \\
S_{2}=\frac{2\left(\pi / 2^{3 / 2}\right) \sqrt{4 F^{2}+1}}{\sqrt{F}}
\end{gathered}
$$

ここに、下は次式で定憧されるリーマルの断面ア スペクト比である。

$$
F=\frac{H}{L}
$$

また、塩水将ーマルの支配方程式である休稹保疗 の式、啠量保存の式および巡坵方程式は式(6) (8) のように与えられる。

$$
\begin{aligned}
& \frac{d}{d t}\left(2 S_{1} H L\right)=q_{e} \\
& \frac{d}{d t}\left(2 S_{1} B H L\right)=0
\end{aligned}
$$

$$
\frac{d}{d t}\left\{2 S_{1} H L\left(1+A_{m}\right) V\right\}=2 S_{1} B H L-2 C_{d} V^{2} H
$$

ここに、B=Hーマルの平均浮力 $\left(=\left(\rho_{0}-\rho_{3}\right) g / \rho_{2}\right)$.

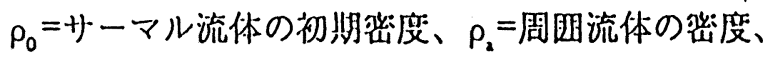
$g=$ 重力加速度、 $V=$ 将ーマルの近心降下速度、 $A_{m}=$ 付加犋量係数、 $C_{d}=$ 抵抗係数、 $q_{\mathrm{e}}=$ サーマールの速行

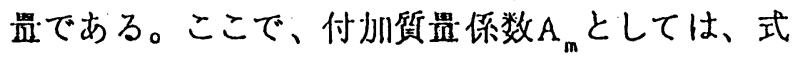
(9)で与えられる楕円帅状SolidBodyのものを用いる。 また、进行は少ーマルの全周四から行なわれると仮 定し、速行係数区 檤入して、式(10)のようにq。 定㧴する。

$$
\begin{gathered}
A_{m}=2 F \\
q_{c}=E_{d} S_{2} \sqrt{H L V} V
\end{gathered}
$$

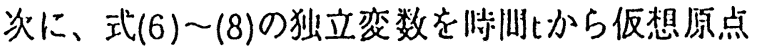
(V.O.)からの距猅正に变挨すると、以下のような登 泟方程式が得られる。

$$
\begin{gathered}
\frac{d H}{d z}=\frac{E_{d} \sqrt{F} S_{2}}{4 S_{1}} \\
\frac{d B}{d z}=-\frac{E_{d} \sqrt{F} S_{2} B}{2 S_{1} H}
\end{gathered}
$$

$$
\frac{d V}{d z}=-\frac{E_{d} \sqrt{F} S_{2} V}{2 S_{1} H}+\frac{B}{\left(1+A_{m}\right) V}-\frac{F C_{d} V}{\left(1+A_{m}\right) S_{1} H}
$$

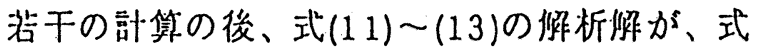
(14) (16)のように得られる。

$$
\begin{gathered}
H=\frac{E_{d} \sqrt{\Gamma} S_{2} \tilde{z}}{4 S_{1}} \\
B=\frac{8 S_{1} W_{0}}{E_{d}^{2} S_{2}^{2} z^{2}} \\
V=\sqrt{\left(\frac{z_{i}}{z}\right)^{\alpha} V_{1}^{2}+\frac{\beta}{\alpha-1}\left(\frac{z^{\alpha-1}-z_{1}^{\alpha-1}}{\tilde{z}^{\alpha}}\right)}
\end{gathered}
$$

ここに、添字沖任㦘点における初拥値を示す。 また、式(16)中のいおよび忙れれそれ次式で与えら れる。

$$
\begin{gathered}
\alpha=4\left\{1+\frac{2 \sqrt{F} C_{d}}{\left(1+A_{m}\right) E_{d} S_{2}}\right\} \\
\beta=\frac{16 S_{1} W_{0}}{\left(1+A_{m}\right) E_{d}^{2} S_{2}^{2}}
\end{gathered}
$$


いま、 $\tilde{z}_{\mathrm{i}}$ は任意であるので、 $\tilde{z}_{\mathrm{i}}=0$ とすると式 (16)は式(19)のようになる。このとき、式(19)から 明らかなように仮想原点 $\tilde{z}=0$ では、 $V=\infty$ となる。

$$
V=\sqrt{\frac{\beta}{(\alpha-1)^{z}}}
$$

以上の僻析解より、サーマル愊Hは落下距崔 $\check{~ に 、 ~}$ 有效重力Bは元のー2乘に比例し、重心降下速度Vは $\tilde{z}$ のー1/2乘にほほ比例することがわかる。

\section{4. 理論モデル中の経験則}

以下では、理論モデルに必哭な経験則について列 挙する。ただし、理諭漽からも明らかであるが、初 期相対密度差 $\varepsilon_{0}$ による傾向的な依存性は実験的にも 認められなかったので、実騟値は各々の初期棇有效 重力W。におる平均値として表示されている。

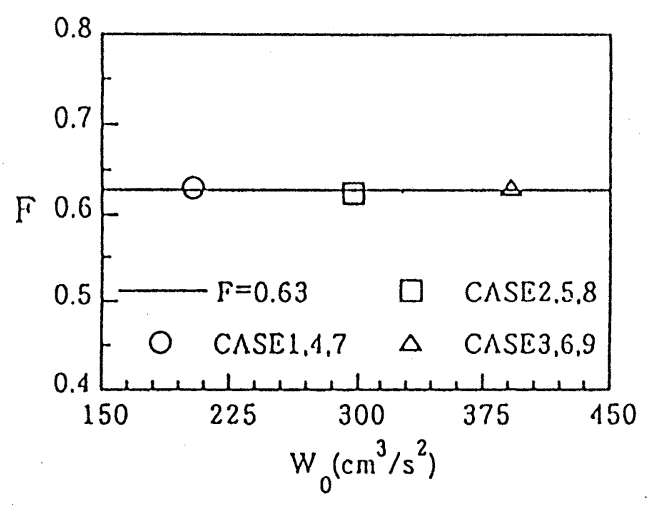

図-4 断面アスペクト比 $\mathrm{F}$ と $\mathrm{W}_{0}$ との関係

\section{(1) 断面アスペクト比F}

図 4 は式(5)で定義される断面アスペクト比 $\mathrm{F}$ 初 期総有效重力W。 れより、FはW。は依存せず、F=0.63で近似でき ることがわかる。

\section{(2) 連行係数 $E_{d}$}

速行係数 $\mathrm{E}_{\mathrm{d}}$ の算出方法には、式(11)から求める方 法 $\left(\mathrm{E}_{\mathrm{a} 1}\right)$ と开ーマル断而皘の恋化集加救める方法 $\left(\mathrm{E}_{\mathrm{d} 2}\right)$ とがあるがの、ここでは $\mathrm{E}_{\mathrm{d}}$ としてすへての $\mathrm{E}_{\mathrm{d} 1}$ と $\mathrm{E}_{\mathrm{d} 2}$ の平均値を採用した。その理由は図5から明らか なように、各 $\mathrm{W}_{0} に お い て \mathrm{E}_{\mathrm{d} 1}$ と $\mathrm{E}_{\mathrm{d} 2}$ との間に著しい差 異が認められないことと、W 的な依存性が認められないためである。

図5より、 $\mathrm{E}_{\mathrm{d}}$ はW 0.43 で近似できることがわかる。この $\mathrm{E}$ 值は $\theta=$ $90^{\circ}$ の傾斜将一マルのE 值 ${ }^{5}$ 上りも約 $20 \%$ 程度大 きくなっている。これは、自由将ーマルでは、対を

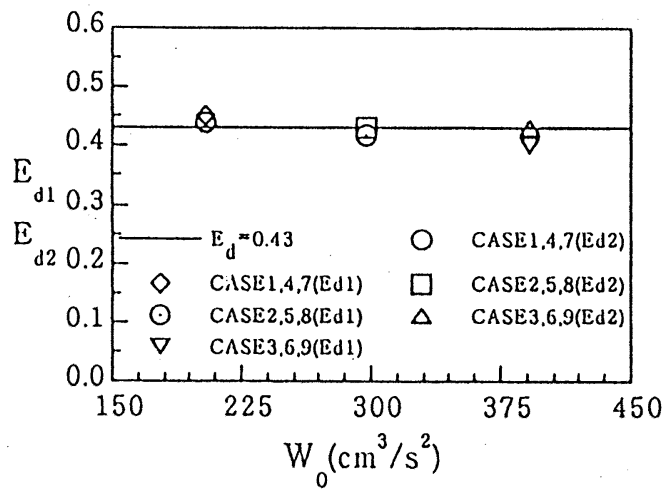

图-5 速行保数 $\mathrm{E}_{\mathrm{d}}$ と $\mathrm{W}_{0}$ との関係

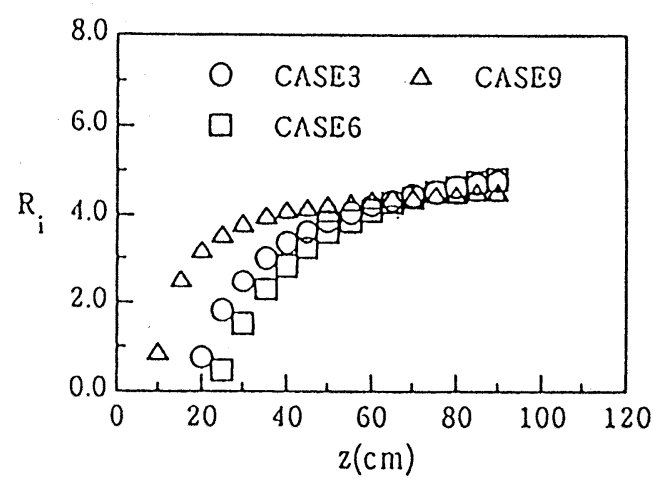

图-6 R 数と落下距離乙との咸係

なす循環流のために連行量がより大きくなるためで あると考えられる。

\section{(3) 抵抗係数 $\mathrm{C}_{\mathrm{d}}$}

乱流サーマルのOverall Richardson数 $\mathrm{R}_{\mathrm{i}}$ を式(20)で 定義すると、支配方程式より $\mathrm{dR}_{\mathrm{i}} / \mathrm{d} \tilde{z}$ の関係式が式 (21)のように得られる。

$$
\begin{gathered}
R_{i}=\frac{2 B H}{V^{2}} \\
\frac{d R_{i}}{d \tilde{Z}}=\frac{3 E_{d} \sqrt{F} S_{2} R_{i}}{4 S_{1} H}-\frac{R_{i}^{2}}{\left(1+A_{m}\right) H}+\frac{2 F C_{d} R_{i}}{\left(1+A_{m}\right) S_{1} H}
\end{gathered}
$$

保存性サーマルでは、式(22)で定義される総有效重 力Wが流下に際してほほ保存されるので、初期総有 効重力W ${ }_{0}\left(=\mathrm{B}_{0} \mathrm{~A}_{0}\right)$ を用いると、式(20)で定義された を数を式(23)のように㫮き换えることができる。

$$
\begin{aligned}
& \mathrm{W}=2 \mathrm{~S}_{1} \mathrm{BHL} \\
& \mathrm{R}_{\mathrm{i}}=\frac{F W_{0}}{\mathrm{~S}_{1} \mathrm{~V}^{2} \mathrm{H}}
\end{aligned}
$$

式(23)のサーマルの $\mathrm{R}_{\mathrm{i}}$ 数と落下距蜼乙との関係を調べ たものの一例が図6である。同図より、サーマルが 発達すると、 $\mathrm{R}_{\mathrm{i}}$ 数が一定值に断近することがわかる。 
流れの礁立領域では、 $\mathrm{R}_{\mathrm{i}}$ 数がそに対してほほ一定 值に渐近することが实験的に確かめられたので、式 (21)において $\mathrm{dR} / \mathrm{d} \tilde{\mathrm{z}}=0$ とすると、抵抗係数 $\mathrm{C}_{\mathrm{d}}$ が式 (24)のように与えられる。

$$
C_{d}=\frac{S_{1}}{2 F}\left\{R_{i}-3\left(1+A_{m}\right) \frac{d H}{d z}\right\}
$$

式(24)の右辺に可规化実験によって算定できる一 定あるいはほほ一定となったR 数やそこでの $\mathrm{dH} / \mathrm{d} z$

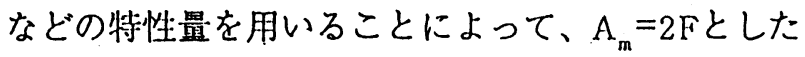
ときのC 值が半理諭的に算定される。このようにし て得られたC 值とW。它の関係を示したものが図7で ある。同図より、得られたC值はW。に刘してほほ 一定值を取ることがわかる。また、本実験のサーマ ルの中で最も十分に発達したものであると考えられ る $\mathrm{W}_{0}=$ 約 $200 \mathrm{~cm}^{3} / \mathrm{s}^{2}$ における $C_{\mathrm{d}}$ 值は $\theta=5 \sim 90^{\circ}$ の傾 斜サーマルの平均的な $\mathrm{C}_{\mathrm{d}}$ 值である $\mathrm{C}_{\mathrm{d}}=0.475^{5)}$ とほほ 同㥞な值を取る。これに比べW $=$ 約 300 と約 $390 \mathrm{~cm}^{3} / \mathrm{s}^{2}$ の場合のC $C_{\mathrm{d}}$ がやや大きいのは、サーマル が発達段階にあるためであると考えられる。なお、 十分に発達したサーマルかそうでないかは、H、 V、Bが式(14)、(15)、(19)の関数関係を满足するか 否かより判断した。 $\mathrm{W}_{0}=$ 約 300 と約 $390 \mathrm{~cm}^{3} / \mathrm{s}^{2}$ にお けるC 值はやや大きく見皘もられているものの、こ こではC 值の全平均としての $C_{d}=0.52$ を採用する。

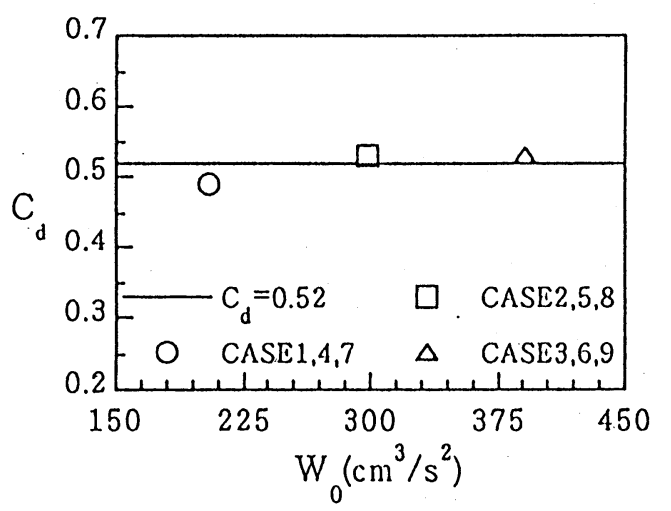

图-7 抵抗係数 $\mathrm{C}_{\mathrm{d}}$ と $\mathrm{W}_{0}$ との関係

\section{5. 解析解と計算值および計算值と実験值との 比較}

図8はCASE2の計算値と理論値との此較結果の一 例であるが、サーマル幅H、平均浮力B㧍よび重心 降下速度Vが完全に一致することがわかる。

図9は、一例としてCASE 2 の実験值 $\left(\varepsilon_{0}=0.26\right.$ 、 $\left.\mathrm{A}_{0}=1.15 \mathrm{~cm}^{2}\right)$ と計算值との定量的な比較を行ったも のである。その際、実験值と計算值との比較を行な うための初期条件は次のように設定した。仮想原点

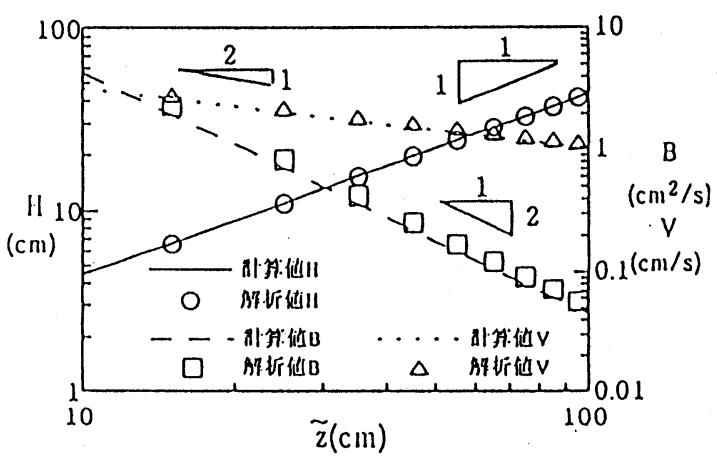

图-8 計算值と理諭値との比较

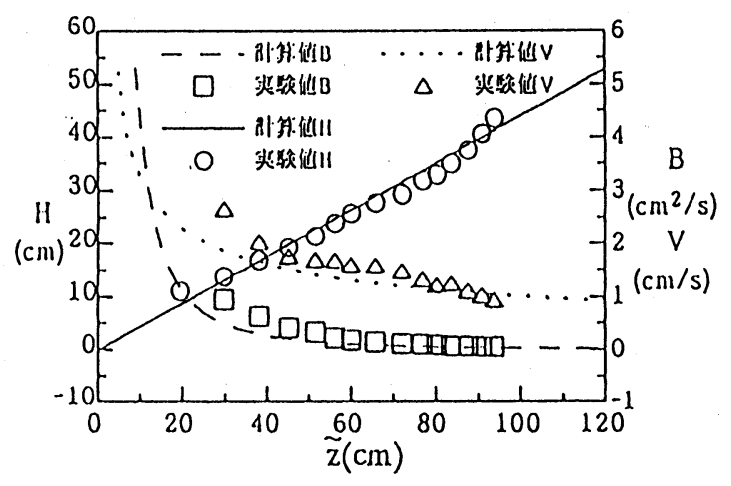

図-9 実験值と計算値との比较

では $\mathrm{H}_{0}=0$ であるが、この条件では計算が発散する ので、 $\mathrm{H}_{0}$ としては極めて小さな值、 $\mathrm{V}_{0}$ としては極 めて大きな值を与え、 $\mathrm{B}_{0}$ はW 算して与えた。具体的な初期值は、 $\mathrm{H}_{0}=0.1 \mathrm{~cm} 、 \mathrm{~V}_{0}=$ $10000 \mathrm{~cm} / \mathrm{s}$ およ゙ $B_{0}=10000 \mathrm{~cm} / \mathrm{s}^{2}$ とした。以上の

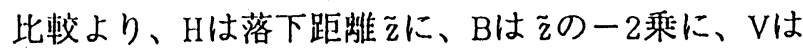
$\tilde{z}$ のー $1 / 2$ 乘に比例することが実験的・理諭的にわ かる。なお、図中の平均浮力Bの值は直接的に实騟 によって求めたものではなく、保存性サーマルでは 総有效重力W。が流下方向に保存されることを利用 して式(22)より算定したものである。

図10、11および12は、 $\mathrm{dH} / \mathrm{d} z 、 \mathrm{dV}^{-2} / \mathrm{d} z$ および $\mathrm{dB}^{-1 / 2} / \mathrm{d} z$ とW $\mathrm{W}_{0}$ との関係についての計算値と実験值 との比較を行なったものである。式(14)、(15)およ び(19)の碀析碀から明らかなように、十分に発達し たサーマルでは、 $\mathrm{dH} / \mathrm{d} z$ はW $\mathrm{d} z$ はW $\mathrm{W}_{0}^{-1 / 2}$ に、 $\mathrm{dV}^{-2} / \mathrm{d} z$ はW $\mathrm{W}_{0}^{-1}$ にそれぞれ比例するこ

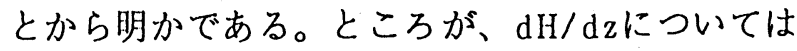
$\mathrm{W}_{0}=$ 約 $200 \mathrm{~cm}^{3} / \mathrm{s}^{2}$ では良く一致しているものの、そ の他のW、についてはやや異なっている。これは、 $\mathrm{W}_{0}=$ 約 300 と約 $390 \mathrm{~cm}^{3} / \mathrm{s}^{2}$ の場合のサーマルの实騟 值が発達段階にあり、 $\mathrm{dH} / \mathrm{d} z$ の実験值が小さくなっ ているためであると考えられる。その結果、 $\mathrm{W}_{0}=$ 約 300 と約 $390 \mathrm{~cm}^{3} / \mathrm{s}^{2}$ の場合のC 值は図7で見たように やや大きめに算定されている。一方、 $\mathrm{dV}^{-2} / \mathrm{d} z に$ 


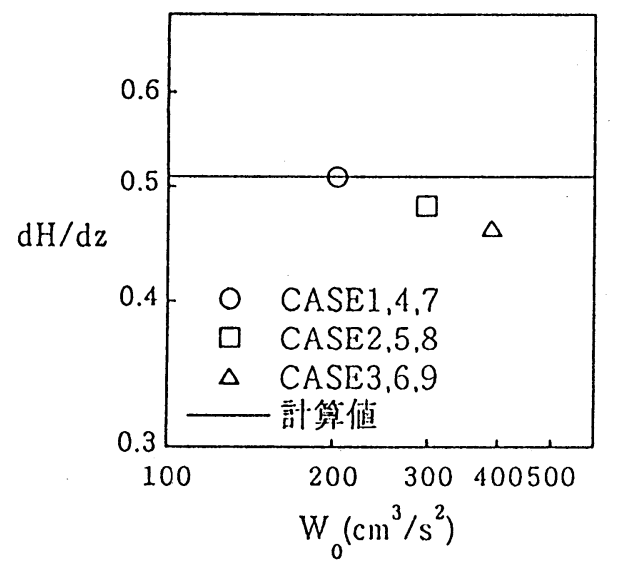

图-10 $\mathrm{dH} / \mathrm{dz}$ とW $\mathrm{W}_{0}$ との関係

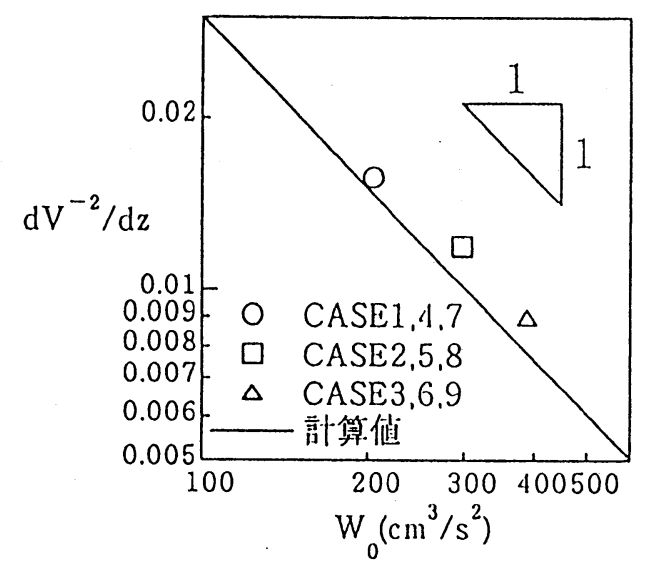

图-11, $\mathrm{dV}^{-2} / \mathrm{d} z$ と $\mathrm{W}_{0}$ との関係

ついては、計算值は実験値のW。に対する依存性を 良好に再現している。しかし、 $\mathrm{dH} / \mathrm{d} z$ の場合と同様 に、 $\mathrm{W}_{0}=$ 約 300 と約 $390 \mathrm{~cm}^{3} / \mathrm{s}^{2}$ では若干の邀いが認

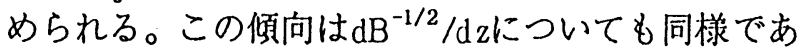
る。最後に、このような流れ現策の解析においては、 抗力項を省略してモデル化することがしばしば行わ れる。そこで、抗力の效果について検討してみよう。 式(14)、(15)、(19)の解析解から明らかなように抗 力の效果は陽的には式(19)の重心降下速度Vにのみ 現われるので、式(19)を用いてVに対する抗力項の 效果を $\mathrm{C}_{\mathrm{d}}=0.52$ と dH $/ \mathrm{dz}$ などの実験值を用いて調べ てみると、抗力項のためVが減少する割合は約 $10 \%$ 程度であることがわかる。よって、第一近似として 自由サーマルの抵抗係数 $\mathrm{C}_{\mathrm{d}}$ を $\mathrm{C}_{\mathrm{d}}=0$ とする従来の解 法は、それなりの䊑度を有していると言える。た だし、 $\mathrm{C}_{\mathrm{d}}=0$ は傾斜サーマルでは楜切な近似とは ならないことに注意する必要がある ${ }^{6)}$ 。

\section{6. 結論}

本研究では、抗力項を含む保存性2次元鉛直自由 サーマルの皘分モデルを藅築し、理諭侈と数值僻お よび数值解と実験值との比較検討を行なった。その 結果、流れの確立領域では、サーマル幅 $\mathrm{H} 〜 \tilde{z}$ 、重

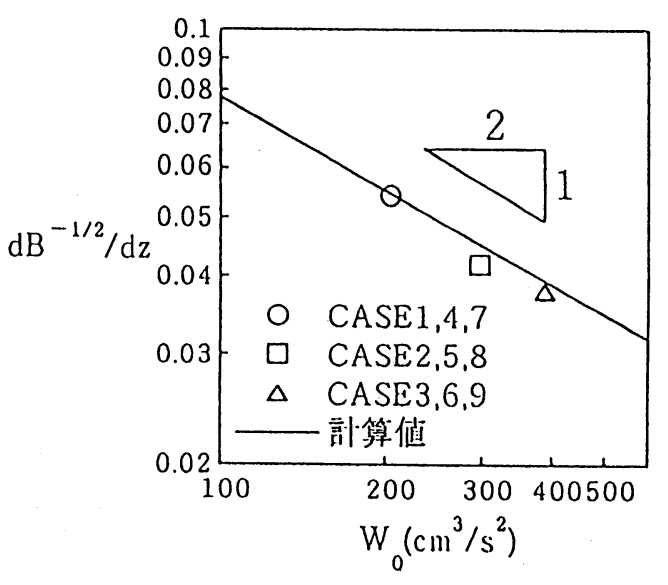

图-12 $\mathrm{dB}^{-1 / 2} / \mathrm{d} z$ と $\mathrm{W}_{0}$ との関係

心降下速度 $V \sim \tilde{z}^{-1 / 2}$ 、平均浮力 $\mathrm{B} \sim \tilde{\mathrm{z}}^{-2}$ なる関係があ ること。 $\mathrm{dH} / \mathrm{dz}$ は初期総有効重力W。に依存しないが、 $\mathrm{dB}^{-1 / 2} / \mathrm{d} z \sim \mathrm{W}_{0}^{-1 / 2} 、 \mathrm{dV}^{-2} / \mathrm{d} \mathrm{C} \sim \mathrm{W}_{0}^{-1}$ なる関係がある こと。流れの確立領域では重力成分と抵抗力および 速行による見かけの抵抗力がバランスすることによっ てOverall Richardson数 $\mathrm{R}_{\mathrm{i}}$ が流下距蜼Zについて一定 となること。抵抗係数 $\mathrm{C}_{\mathrm{d}}$ は $\mathrm{C}_{\mathrm{d}}=0.52$ 程度、連行係数 は $\mathrm{E}_{\mathrm{d}}=0.43$ 程度の值を取ること。抗力項のためVが 減少する割合は約 $10 \%$ 程度であることなどがわかっ た。今後、今回得られた知見を基に固液混相濁水开一 マルの流動・拡散現象について検討寸る予定である。

謝辞：本研究の一部は、文部省科学研究費、(代表 者：秋山壽一郎、諃題番号08455232)の援助を受け た。ここに記して感謝の意を表します。

\section{参考文献}

1) 玉井昌宏・村岡浩酥・室田明：固体粒子群の落下挙動 と誘起流動に関する片究、上木学会䜽文集、No.509/ II 30、pp.143.154、 1995.

2) Baines, W.D \& Hopfinger, E.J. : Thermals with large density difference, Atomospheric Enviroment, Vol. 18, No. 6, pp. 1051-1057, 1984.

3) Wang, C.P. : Motion of an turbulent buoyant thermal in a calm stably stratified atmosphere, The Physics of Fluid, Vol. 16, No.6,pp.744-749,1973.

4) Escudier, M.P. \& Maxworthy, T. : On the motion of turbulent thermals, J. Fluid Mech, Vol. 61, part 3, pp. $541.552,1973$.

5) 秋山言一郎、泊 滕、富岡直人、今宮盛雄：保存性 2 次元倾斜サーマルの流㗢特性の予测、水工学諭文菒、 第40巻、pp.555.560、1996.

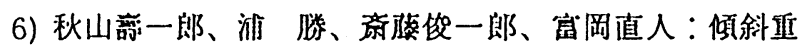
力密度流の速行係数に関する統一的考察、ながれ、第 16卷、日本流体力学会、pp.149·161、1997.

(1997.9.30受付) 